\title{
ACCENTED SPATIAL REPRESENTATIONS IN THE INTERNAL EXILIC EELAM-TAMIL FILM VIDUTHALAI MOOCHU
}

\author{
Ramesh Loganathan \\ English Language Teaching Centre \\ Ministry of Education Malaysia \\ rameshlogan@gmail.com \\ Shanthini Pillai \\ Faculty of Social Sciences and Humanities \\ Universiti Kebangsaan Malaysia \\ spillai@ukm.edu.my \\ Pramela Krish \\ Faculty of Social Sciences and Humanities \\ Universiti Kebangsaan Malaysia \\ pramela@ukm.edu.my
}

\begin{abstract}
Studies have shown that accented filmmaking features and strategies are indeed appearing in wide-ranging films of contemporary cinemas. The main focus of this paper is to analyze Viduthalai Moochu, an internal exilic Eelam-Tamil film from Sri Lanka, using a concept derived from Hamid Naficy's theorization of An Accented Cinema known as the "preoccupation with the place." The concept is cinematically expressed through the open, closed, and third spacetime cinematic formations. It needs to be noted here that Naficy's theory offers a range of accented cinematic features that express accent in the film. However, the paper will only focus on the film's spatial representations that are configured according to the space-time formations. Space-time formations are cinematic features that are employed to produce and reproduce the "accent" through cinematic representations of spaces and places rendered in the film. The configurations of the space-time formations will be used as the basis to examine Viduthalai Moochu, a film that does not seem to demonstrate the familiar conventions of filmmaking. The film mainly grapples with themes that enunciate the Eelam-Tamil displacement and deterritorialization in the internal exilic situation. The analysis shows how a particular version of alternative filmmaking strategy exclusively uses spatial representations to render themes
\end{abstract}


of displacement and deterritorialization. The findings prove that the makers of Viduthalai Mooch $u$ have indeed employed the space-time formations to highlight the displacement and the deterritorialization of the Eelam-Tamil community through cinematic spatial representations.

\section{Keywords}

accent; deterritorialization; displacement; preoccupation; space-time.

\section{About the Authors}

Ramesh Loganathan is currently pursuing his $\mathrm{PhD}$ in the field of Postcolonial Literature at the National University of Malaysia. He obtained his MA from the University of Malaya.

Shanthini Pillai, PhD is Associate Professor at the Faculty of Social Sciences and Humanities, and Associate Senior Research Fellow at the Institute of Ethnic Studies (KITA), National University of Malaysia (UKM). Her research interests are anchored primarily in ethnic diversity, diaspora, and transnationalism in literary and cultural texts with particular reference to the global South Asian diaspora. An emergent interest is in the cultural consciousness of Catholic diasporic Indians and Chinese in Malaysia.

Pramela Krish is Associate Professor at the Faculty of Social Sciences and Humanities, Universiti Kebangsaan Malaysia. She has researched and published works on online learning and teacher professional development. Her research interests include technology-based language learning and the impact of new media in society.

Kritika Kultura 33/34 (2019/2020): 477-502

(c) Ateneo de Manila University

<http://journals.ateneo.edu/ojs/kk/> 


\section{INTRODUCTION}

The mid-196os saw an increase in films focusing extensively on mobile human populations around the world. This discerned film movement mainly comprised of films that mostly focused on issues related to the fractures of the social fabric as a result of terrorism, genocide, revolution, civil war, and colonization; these films mainly concentrated on issues related to forced expulsions, displacement, and deterritorialization. Eventually, these films were grouped under the rubric that became popularly known as the accented cinema. In tandem with the current development of film scholarship in academia, accented films, over the years, have become increasingly recognized as an emergent body of work and a genre that could arguably shed light to the many ambivalences and complexities that still plague the study of diaspora, exile, and postcolonial ethnicity.

\section{AN ACCENTED CINEMA AND THE ACCENT}

According to Asuman Suner, Hamid Naficy's An Accented Cinema is a filmbased theory that offers the most comprehensive account of the emerging field of accented filmmaking in terms of both the time span and the range of films that it covers (1). As a conception that originates from Hamid Naficy's pioneering work on the "independent transnational cinema." Naficy describes accented cinema as a potential genre that is able to "cut across previously defined geographic, national, cultural, cinematic, and meta-cinematic boundaries" (1). Importantly, the theory offers a classification model that methodically categorizes the accented art films and the filmmakers according to the three known forms of displacement and deterritorialisation, that is, the exilic, the diasporic, and the postcolonial ethnic.

Naficy's cinematic classification model categorically distinguishes the filmmakers and their films based on the experiences and forms of fracture. The model is strongly inspired by the fractured filmmakers' fetishization toward the homeland, both the old and the new, along with other external and internal factors that had previously or currently influenced the displacement and deterritorialization of the filmmakers. The model specifically focuses on the filmmakers' emotional bond or their attachment with the spaces and places they had previously inhabited or currently inhabiting, that is, the old and the new homeland. The answer to the question of what makes the accented style distinct from other cinemas, the answer is undoubtedly the accent.

Fundamentally, the accented style is strongly driven by the filmmakers' accent. According to Naficy, the accent, in this regard, refers exclusively to the filmmakers' 
experiences of displacement and deterritorialization-not necessarily their spoken lingo-including the filmmakers' psychological displacements. According to Subeshini Moodley, the accent also stems from the various factors that had influenced the filmmakers' displacement, for instance, the filmmaker's origin, causes of displacement, the time frame or the period involved, and the filmmaker's geographical background. Reasoning from these explications, it can be argued that the accent which forms the crux of accented cinema primarily originates from the displaced and deterritorialized filmmakers' preoccupation with spaces and places.

\section{ACCENTED FILMMAKERS' PREOCCUPATION WITH SPACES AND PLACES}

The preoccupation with spaces and places is one of the central concepts delineated in the theorization of An Accented Cinema. The concept identifies the filmmakers' emotional bond with the past and present, and the loved and hated homeland. The concept exposes the filmmaker's "utopian yearning for faraway utopian places, homesick nostalgia for the past, the schizoid perception of the present, loss of identity and belonging, and desire for social others and foreigner(s)" (Naficy 206). As a significant conception of the theory of An Accented Cinema, the filmmakers' preoccupation with spaces and places not only emphasizes the bond with the native homeland but also accentuates the accented filmmakers' perseverance in developing their new bond with the adopted homeland.

It needs to be highlighted that most accented filmmakers had never failed to express their deep sense of attachment and sentiments toward the spaces and the places they inhabit. Three such examples are Song of the Exile (dir. Ann Hui, 1990), Distant (dir. Nuri Bilge Ceylan, 2002), and No One Knows about Persian Cats (dir. Bahman Ghobadi, 2009). From these films, it is obvious that the filmmakers' attachment and sentiments are usually related to issues of territory and territoriality that are influenced by the experiences of expulsion from the native homeland and the displacement in the adopted homeland. On this point, Naficy stresses that regardless of their fractured experiences and disposition, the accented filmmakers' bond with both the old and the new homeland is usually overtly or covertly expressed through a range of prescribed accented cinematic features, such as the space-time formation modality, journeys, borders and journeying, thematic tropes, spoken lingo, electronic and textual epistolarity, employment of self-reflexivity, self-inscription, asynchronous sound, and multilinguality, to name a few.

To this end, the paper will explore how the filmmakers' use of the spatial and temporal representation of the open, closed, and third space-time formations to express the accent of displacement and deterritorialization in the internal exilic 
Eelam-Tamil film, Viduthalai Moochu (Freedom's Breath, dir. K. Ramaesh and S. Vinothan, 2002). To begin with, we will briefly explain the spatial and temporal characteristics of the open, close, and third space-time formations.

\section{THE SPACE-TIME FORMATIONS}

In the theorization of An Accented Cinema, Naficy uses the open, closed, and the third space-time formations as the "unit of analysis for studying texts in terms of their representation of spatial and temporal configurations and as an 'optic' for analysing the forces in the culture that produce these configurations" (152). The space-time formations are also cinematic features that are employed to examine connections between the "inherited space-time of the homeland to the constructed space-time of the exile and diaspora" (152). These formations demonstrate how the spatial and temporal representations of the homeland in the conditions of either the diasporic, exilic, or postcolonial ethnic setting are cinematically conveyed through the open, closed, and third space-time formations. All the three space-time formations are inherently place-bounded and refer "to certain specific temporal and spatial settings in which stories unfold" (152). In what follows, we will briefly discuss the pre- and post-Eelam-Tamil civil war experience in Sri Lanka specifically focusing on the Eelam-Tamil displacement and the emergence of post-civil war Eelam-Tamil accented films before we make a reading of the space-time formations in the selected scenes.

\section{Civil War and Displacement}

In the Sri Lankan Civil War (1983-2009), it is estimated that more than 60,00o Eelam-Tamils were killed and 1,017,0oo were displaced (Colletta, Lim, and Kelles-Viitanen 384-385). Ever since, the internally displaced Eelam-Tamils, a visibly marginalized population, has been increasing in the island nation of Sri Lanka. Conspicuous in their isolation for reasons that are obvious, the existence of the internally displaced Eelam-Tamils has certainly changed, for the worse, the perception toward the land which was once known as the island paradise. By looking at the history of the Eelam-Tamils in Sri Lanka, it is evident that the Civil War was an inevitable outcome of the age-long Eelam-Tamil struggle for identity and sense of belonging. According to Bartholomeusz and Silva, despite centuries of dwelling side by side with the dominant and other ethnic minorities, the EelamTamils, the largest ethnic minority of Sri Lanka, has always been construed as the "other" (6). 
Throughout the years, Sri Lanka had witnessed many ethnic upheavals which resulted from the Eelam-Tamils' struggle to prove that they too were natives of the Sri Lankan soil. Even though there is historical and archaeological evidence that supports this claim, the Eelam-Tamils were never officially considered as Sri Lankans. In fact, the term Sri Lankan exclusively refers to a Buddhist person who lives in Sri Lanka, the term never included the Eelam-Tamils in terms of political, cultural, and even symbolic representations (Koneswaran). In the post-Sri Lankan independence era, the age-long marginalization of the Eelam-Tamils culminated in a series of communal racial tensions, and dissatisfaction between the dominant majority and the lesser minority became more apparent and threatening. The possibilities of a civil war thickened due to the rising ethnic and political pressures. In the mid-fifties, Sri Lanka witnessed the most gruesome "[politically] motivated ethnic uproars in the year[s] 1956, 1958, 1977, 1981 and 1983" (Samaranāyaka 36). The Sri Lankan Civil War was "one of the world's least known but longest-running and bloodiest armed conflicts, one that has cost thousands of lives" (Roy and Gates 176).

The Civil War which began in 1983 lasted for more than two decades. In this period, a total of four Eelam wars were fought: "Eelam War 1 (1983-1987), Eelam War 2 (1989-1994), Eelam War 3 (1995-2002) and Eelam War 4 (2006-2009)" (Houen 80). In May 2009, the Eelam-Tamils were militarily defeated by allied forces led by the Sri Lankan Military. The defeat marked the end of Asia's longest-running wars (Fernando, Bandara, Liyanaarachch Jayathilaka, and Smith 580). At the end of the Civil War, "the Sri Lankan government claimed that Sri Lanka was the first nation in the modern world to eradicate terrorism on its own soil" (Weerawansa). The remaining Eelam-Tamils were captured, some of them were sentenced to death, and most were forced into internal exile. Other than the Eelam-Tamil minorities, other indigenous ethnic minorities such as the Burghers and the Moors suffered the same fate as the Eelam-Tamils. According to Debra Kalmanowitz and Bobby Lloyd, "the Civil War affected all people regardless of ethnic group, religion and geographical location" (187). The war had also brought drastic changes to the landscapes of Sri Lanka and the rest of the world. It is estimated that one-third of Sri Lankan Eelam-Tamil population was driven out of the war-torn nation. In reality, "the civil war has led to more than 800,ooo Eelam-Tamils leaving Sri Lanka," a much more significant number compared to the international labor migration during the British colonial period (Sefton-Green and Rowsell 152). The Civil War era witnessed the most devastating mass migration of the Eelam-Tamils to the other parts of the world as refugees and asylum seekers. 


\section{THE POST-EXPULSION EELAM-TAMIL DISPLACEMENT}

The series of ethnic wars had indeed stripped the Eelam-Tamils of everything. Those who survived the Civil War were further divided. The Eelam-Tamils who stayed back were forced into internal exile in the mainland area of the Northern Province, a region called Vanni. The Eelam-Tamils who migrated became international diasporic communities. Among the countries, Canada became the most soughtafter destination for the Eelam-Tamil migrants who left Sri Lanka. The external and internal expulsion of the Eelam-Tamils can be seen as the most devastating repercussion of the Sri Lankan Civil War. The era marked the displacement of the Eelam-Tamil ethnic minority not only in Sri Lanka but also in the other parts of the world, especially in Canada. In 1999, "Sri Lanka was the leading source country of refugee claimants to Canada"; at that point of time, "Canada was hosting the single largest Sri Lankan diaspora of any country" (Hyndman 1). The remaining Eelam-Tamils who stayed back were driven out of their traditional villages and were forced into military-controlled restricted areas which are also widely known throughout the world as safe zones of the Vanni region. In this paper, the spaces and places where the Eelam-Tamils are internally exiled will be referred to as the internal exilic enclosure. In describing her experience in the exilic enclosure, Jane Derges writes that contaminated food, inadequate shelter, cholera, malaria, and dengue were rife at the internal exilic enclosure (95).

\section{THE EELAM-TAMIL INTERNAL EXILIC EXPERIENCE}

The post-Civil War era is not only a period that saw the mass expulsion of the Eelam-Tamils from the native homeland, but also a period that witnessed the displacement of the Eelam-Tamil experience in its own birth soil. The remaining Eelam-Tamils who refused to part from the native Eelam-Tamil homeland were eventually evacuated from the traditional villages, and subsequently, they were relocated by force into the military-controlled internal exilic enclosure. In his book, Boyle describes the internal exilic enclosure as the spaces and places where the Eelam-Tamils were subjected to unimaginable torment (19). In a conversation with the Los Angeles KPFK radio host, Michael Slate, Boyle openly accused the ruling regime of "bulldozing and destroying evidence of massacres in the internal exilic enclosure while preventing access to the Red Cross and UN agencies" (19). Besides the loss of native homeland, possessions, and the lives of their loved ones in the internal exilic enclosure, the Eelam-Tamils were ostracized and stripped of their identity. 
THE POST-CIVIL WAR AND EELAM-TAMIL LITERATURE

The post-Civil War era saw uncertainty and gloom spread across the native EelamTamil homeland, that is, the northern half and eastern province of Sri Lanka. At that point, the Eelam-Tamils experienced drastic sociocultural changes. In some ways, the loss of the native Eelam-Tamil homeland and the displacement experiences, both internal and external, impacted the Eelam-Tamil literature.

The Civil War which spanned for almost three decades had destroyed most of the Eelam-Tamil literary heritage. One such example is the burning of the Jaffna library which saw over "95,000 volumes of numerous culturally important and irreplaceable manuscripts destroyed" (Brown and Hamad 87). In the internal exilic enclosure, the Eelam-Tamils were stripped of everything that had defined them; the internal exilic disposition left the Eelam-Tamils economically, politically, culturally, and even symbolically defeated. The defeat, loss of homeland, internal exilic predicament, and displacement, in a way, became the impetus for the revival of Eelam-Tamil literature. The Sri Lankan Civil War and the Eelam-Tamil internal exilic experience became known globally and were imagined in various forms of popular culture throughout the world. Thematic representations of the EelamTamil experience gained popularity in most literary and nonliterary genres. In the '8os and the ' 90 s, many South Indian Tamil filmmakers began exploiting the EelamTamil dilemma of Sri Lanka and the devastations of the ethnic Civil War in their films. The Sri Lankan Civil War has also inspired a video game, Tom Clancy's Ghost Recon Predator. The post-Civil War era also witnessed the emergence of accented Eelam-Tamil films which rendered the post-Civil War Eelam-Tamil predicament through the eyes of the displaced Eelam-Tamil filmmakers.

\section{ACCENTED EELAM-TAMIL FILMS}

The emergence of the Eelam-Tamil diasporic and internal exilic Eelam-Tamil accented films gives evidence to the beginning of post-Civil War Eelam-Tamil literature in Sri Lanka. It needs to be highlighted that the Civil War which spanned for almost three decades had wiped out most of the Eelam-Tamil literary heritage. Although, the post-civil war accented Eelam-Tamil films were produced in different geographical locations, mainly in Canada and Sri Lanka, these films are found to be thematically similar. Both movements primarily focused on themes that enunciated the effects of the Civil War, the Eelam-Tamil dilemma in internal exile, and the nostalgia and the loss of the native Eelam-Tamil homeland. 
The post-Civil War era which distinctively marked the displacement and deterritorialization of the Eelam-Tamils can also be seen as the awakening period of the contemporary Eelam-Tamil literature in Sri Lanka. The emergence of the exilic Eelam-Tamil and diasporic Eelam-Tamil films gave fresh breath to the modern Eelam-Tamil literature and contributed immensely to its revival experiences. The Eelam-Tamil accented films can also be seen as both creative literary works of the contemporary Eelam-Tamil experiences and also artistic productions that reinforce the Eelam-Tamil belonging, identity, thoughts, culture, and behavior. The EelamTamil accented films focused immensely on the Eelam-Tamil dilemma, mainly the ostracization, subjugation, oppression, marginalization, and confinement at the internal exilic enclosure as well as the loss, civil war trauma, and alienation in Canada. Hence, it can be summed that the post-civil war dilemma had roused the call for a liberated Tamil Eelam, a call to unite and reclaim the lost Eelam-Tamil traditional homeland.

To most Eelam-Tamils, the Tamil Eelam is the embodiment of a once liberated and celebrated Eelam-Tamil homeland which existed before the arrival of the colonizers. To date, the diasporic Canadian Eelam-Tamil accented films have gained outstanding recognition worldwide. Many of these films had won numerous awards and recognitions in the international film arena. As for the internal exilic Eelam-Tamil films, though these films do not have any recognition in Sri Lanka, these accented artistic films are successfully striving on social media to this very day.

\section{INTERNAL EXILIC ACCENTED EELAM-TAMIL FILMS}

Although the Eelam-Tamil accented films from Canada and Sri Lanka artistically render the post-Civil War Eelam-Tamil dilemma, the paper will only focus on the internal exilic Eelam-Tamil accented films. There are two main reasons for this: first, besides being one of the largest ethnic minorities that has been internally exiled in Sri Lanka and also in the context of South Asia, thus far, the Eelam-Tamil internal exilic experience has not received much attention in the field of academia. Second, it will certainly be worthwhile to explore the internally exiled Eelam-Tamil filmmakers who are still working in the interstices of cultures and film practices; these filmmakers are the displaced and deterritorialized artisans who simultaneously play the roles as both the outsiders and insiders in their films. Naficy argues that the internally exiled filmmakers, compared to the other accented groups of filmmakers, are subjected to the tremendous toll of exilic experience, and they also face "restrictions, deprivations, and censorship" (11). In certain totalitarian countries, exilic filmmakers are treated as outlaws, and their works are usually banned. It will 
be certainly interesting to explore how the constraints and restrictions that are imposed on the filmmakers provoke them to develop anarchistic authorial styles; these outlawed artisans and their strategies have not received much attention in the field of literary academia. Among other things, there is a certain distinction between the filmmakers who are externally exiled and the filmmakers who are internally exiled. According to Naficy, the internally exiled filmmakers voluntarily make decisions to stand their ground and refuse the prospects of escape in order to "fight the good fight" at home. Naficy calls this "a fight that often defines not only their film style but also their identity as oppositional figures of some stature” (11).

\section{INTERNAL EXILIC FILMMAKERS}

Viduthalai Moochu is a film which is directed and independently produced by two internal exilic Eelam-Tamil filmmakers, K. Ramaesh and S. Vinothan. The aesthetic features of the film as well as the description and characteristics of both the filmmakers are certainly congruous to the accented film and accented style of filmmaking. In his book, Naficy defines accented filmmakers as the fractured, displaced, and deterritorialized artisans who make films to convey specific messages or meaning, in every aspect, these filmmakers are distinct from the mainstream or other regular filmmakers. According to Naficy, accented filmmakers, "operate independently, outside the studio system or the mainstream film industries, using interstitial and collective modes of production that critique those entities" (10). The makers of Viduthalai Moochu, K. Ramaesh and S. Vinothan certainly fit Naficy's explication of the "unknown artisans" of the cinema world, especially those who are of the internal exilic background. Compared to the diasporic, external exilic, and postcolonial ethnic filmmakers whose works are admittedly becoming increasingly significant in the film arena, the internal exilic filmmakers are the artisans who are lesser known or often not known at all. The reason could be that the practices of the internal exilic filmmakers are mostly isolated, and their works usually do not conform to the standards and practices of the mainstream or the other cinemas. Although there are various reasons for this, we posit that the most pertinent one is that the politically suppressed voices of the internal exilic filmmakers may never be heard. As filmmakers who come from the internal exilic experience, the makers of Viduthalai Moochu also share the same fate as the other internal exilic filmmakers; both K. Ramaesh and S. Vinothan are only known through the film's credits. It needs to be stressed here that internal exilic filmmakers work under tremendous toll in totalitarian countries. According to Ezra and Rowden, some internal exilic filmmakers may even risk interrogation, censorship, imprisonment, and even their lives for making films that go against the ruling regime (112). In the same way as Viduthalai Moochu, internal exilic films usually thrive on popular online video 
platforms (OVP) such as YouTube, Vimeo, and Dailymotion. First published on YouTube in 2013, Viduthalai Moochu has thus far garnered 239,565 views, and the film has been viewed throughout the world.

\section{VIDUTHALAI MOOCHU}

\section{A BRIEF SYNOPSIS}

The film Viduthalai Moochu (Freedom's Breath) portrays the predicament of the internally exiled Eelam-Tamils living in the internal exilic settlement where the Eelam-Tamil people are forcefully evacuated from their native villages and ostracized from the predominant Sri Lanka society and other ethnic minorities. As a narrative of the Eelam-Tamil internal exilic experience, Viduthalai Moochu is strongly inspired by the post-Civil War Eelam-Tamil consciousness. The film's catchphrase spells this out clearly: "for our dignity and our land." The film revolves around the lives of the Eelam-Tamil exiles who have been banished to a remote military-controlled exilic enclosure. Consistent with the notion of banishment, the Eelam-Tamil characters in this film do not go by names and, in most scenes, these characters are intentionally muted by the filmmakers. The film brings to light the ruthless control of the oppressors through the representations of fear, rape, repressive control, death, and torture. Every scene in the film portrays the never-ending torments experienced by the Eelam-Tamil internal exiles in the state designated exilic settlement. The feature film, which runs for a good 99 minutes, does not have the slightest indication of entertainment or commercial elements.

The film's plot is mainly about how the tyrannized Eelam-Tamil people are forced to a breaking point where they start retaliating against their oppressor. The film bears a substantial resemblance of the exilic filmmaking style which is evident in all the scenes in the film, each scene in the film demonstrating the signs and symptoms of anarchism. It is quite common for accented filmmakers to take on themes that enunciate anarchism as a way of talking back or to oppose the oppressive ruling regimes. Although the film does contain subjects and visuals that are anarchist, however, the film does not, in any way, reflect or highlight the nation's ongoing political dogma.

Viduthalai Moochu mainly renders the ongoing sufferings endured by the Eelam-Tamil internal exiles in the hands of the oppressor in the state-controlled internal exilic enclosure. The film clearly illustrates how torture, suppression, marginalization, and phobic experiences reinforce negative beliefs and eventually evince into rebellious retaliation. Through this film, the filmmakers, K. Ramaesh 
and S. Vinothan, draw attention to the driving force of the Eelam-Tamil psyche: the Eelam-Tamil consciousness which is illustrated through a series of revolt against the oppressor. The film ends with one of the shelters being forcefully taken over. The scene shows the perpetrators being avenged and the rest of the army personnel being chased away by the inhabitants of the shelter.

\section{FRAMING A RECONDITE POPULATION USING THE OPEN, CLOSED AND THE THIRD SPACE-TIME FORMATIONS}

Naficy observes in his book that, unlike many accented films, Viduthalai Moochu is a feature film that has not received the kind of attention and recognition like other regular accented films. Until now, the film has not made it to the screens and would probably remain unnoticed for times to come. As an accented visual narrative of internal exile, the film articulates the internal exilic predicament through the internal exiles' point of view. The film stresses the significance of the Eelam-Tamil consciousness, a deep-rooted psyche that underlines the Eelam-Tamil point of view in expressing the accent of displacement and deterritorialization of the Eelam-Tamil experience in internal exile. The film also demonstrates the use of a range of the accented cinematic features, such as journeys, the spatial representation modality of the open, closed, and third space-time formations, epistolarity, asynchronous sound, multilinguality, and accented speech. Although there are a number of accented cinematic features employed in the film, the spacetime formations appear to be the most effective in rendering the filmmakers' preoccupation with the spaces and places. In the film, besides the renderings of the internal exilic enclosure, the open, closed, and third space-time formations play a significant role in conveying the effects of displacement and the deterritorialization experienced by the filmmakers and the rest of the Eelam-Tamil community.

The portrayal of spaces and places in the film which is rendered through the influence and the strategies of the space-time formations effectively convey the notion that the fractured filmmakers have also "constructed an idea of a 'lost ancestral home' in the interstitial space between history and dreams, and on the shifting sands of nostalgia and memory" (Herrera 177). The notion refers to a common discourse in most exilic scholarly works, that is, the displacement and deterritorialization experiences of the fractured that has been consistently observed in the study of postcolonial literature. In the film, the experiences of displacement and the deterritorialization of the internally exiled Eelam-Tamil community are highlighted effectively through the spatial configuration of the open, closed, and third space-time formations. 
Using the concept of the space-time formations, we will analyze three selected scenes from Viduthalai Moochu to see how the spatial and temporal dimensions of the three cinematic features are employed as strategies to express the film's accent and its internal exilic disposition. Compared to the other scenes in the film, the three selected scenes best illustrate the particular use of the open, closed, and third space-time formations.

\section{OPEN SPACE-TIME FORMATIONS}

Apart from visually expressing the fractures of social fabric, accented films also play a pivotal role in revealing the displaced and deterritorialized filmmakers' intents or their determinations to inhabit spaces and places that resemble the lost homeland. According to Naficy, spaces and places such as these are known as the "utopian prelapsarian space-time" of the imagined homeland that is uncontaminated by "contemporary facts" (152). The accented cinematic version of utopian prelapsarian space-time formations normally refers to spaces and places that remind the filmmakers of their lost and revered homeland which was once visually luxuriant and liberated. The cinematic renderings of such spaces and places are usually illustrated visually through the use of wide and open framings which brings the views of the landscapes that filmmakers believe represent the lost idolized homeland(s). Views such as these are usually conveyed through long and mobile camera shots that would reveal the aesthetic aspects of the spaces and places rendered in the film such as "external locations and open settings and views of landscapes, bright natural lighting, and mobile and wandering diegetic characters" (Naficy 153). External locations, open settings, and sweeping views of landscapes are the prescribed aesthetic aspects of the open space-time form. Aspects such as these are usually perceived as the visual markers of the idolized desired homeland.

In the accented style of filmmaking, the representations of the open space-time formation, in appearance, are characteristically pictorial, liberated, and extensive; views such as these are usually expressed through the use of bright natural lighting which solely relies on natural sunlight. Unlike other filmmaking styles, the accented style does not rely on artificial lighting schemes. Apart from framings, camera shots, and lighting scheme, one more prescribed aspect of the open space-time formation is the existence of the diegetic characters. Gerald Prince argues that unlike documentary commentators and conventional characters of mainstream cinema, the "diegetic characters are actual characters in the film who narrate, tell and recount the story and summarise and make comments on the events that make up the film's plot, these actions are usually conveyed through the narrator thoughts" 
(1984). The narration and the thought processes of these characters are known as the diegesis.

\section{CLOSED SPACE-TIME FORMATIONS}

Besides the open space-time formation, the closed space-time formation is also a vital space-time formation that renders the spatial and temporal characteristics of spaces and places illustrated in most accented films. In the accented filmmaking strategy, the closed space-time is a spatial and temporal formation that is characterized by the filmmakers' preferences of filming in spaces and places that convey the idea of restriction, confinement, trauma, and claustrophobia. In the accented filmmaking style, the manifestations of the closed space-time formations are mostly represented through urban and oppressive landscapes. According to Catherine Fowler and Gillian Helfield, the urban landscapes represent the notion of suppression and delimitation rather than perpetuity and amplification. The landscapes that are rendered through the configuration of the closed space-time formation "express a strong sense of claustrophobia: compressed and clogged with the detritus of city life" (3). The spaces and places that are rendered through the closed space formations also represent a sense of mental, physical, or even metaphorical confinements. The characters who inhabit or occupy these spaces and places are often shown experiencing "restrictions in movements and perspectives by spatial, bodily, or other barriers" (Naficy 153). Such illustrations are usually rendered through "tight shot composition, static framing, and barriers and shots that focus on closedness" (Naficy 153). The mise-en-scène of the scenes that are rendered through the configuration of the closed space-time primarily consists of "interior locations and closed settings, such as prisons and tight living quarters, a dark lighting scheme that creates a mood of constriction and claustrophobia" (Naficy 153).

\section{THIRD SPACE-TIME FORMATIONS}

The final configuration of Naficy's spatial and temporal representation modality is the third space-time formation. The third space-time is a configuration that is "formed through the decussation of the open and closed space-time formations" (Naficy 212; Gow 70). Continuing from Naficy and Gow, Lance Hanson asserts that unlike the open and closed space-time formations, the third space-time markedly represents the notion of temporariness through liminal and transitional spaces and places (7). Christopher Gow calls spaces and places such as these as the structures 
of slip zones (70). According to Naficy, as an amalgamated form of the open and the closed space-time formations, the third space-time formations are spaces and places that best illustrate the "characteristics of exile" (212). Naficy asserts that in terms of ethos, those who occupy the spaces and places of the third space-time formations are no longer fixated on the notion of originality. In these spaces and places, "they are presented not discretely but in a structure of play of sameness and difference, of authenticity and translation" (Naficy 213). In most accented films, the representations of the third-space formations are usually represented by spaces and places such as travel, crossings, border spaces, and journeys. The common manifestations of the third space-time formations are "borders, tunnels, seaports, airports, and hotels or means of transportation, such as trains or buses" (Naficy 5).

As cinematic features that convey the accent of displacement and deterritorialization through the means of spatial and temporal representations, space-time formations are not always definite structures. For instance, in an accented film, there may be a few scenes composed according to a defined spacetime formation and some scenes according to multiple formations. According to Naficy all the three formations may at times "reinforce, coexist with, or contradict one another" (Naficy 153).

\section{THE OPEN SPACE-TIME FORMATION IN THE PADDY FIELD AND THE GRAVE SCENE}

Although there are few scenes in the film that exhibit the characteristics of the open space-time formation, the paddy field and the grave scene best reflects the spatial and temporal markings of the open space-time formation. In this scene, a young Eelam-Tamil boy from the shelter is shown collecting left-over grains from a paddy field near the shelter where he lives. The following frame shows the boy collecting the scattered grains in the paddy field; while he was doing this, the boy accidentally bumps into several dead bodies. Presumably, these were the bodies of the EelamTamils who had been killed by the military. Traumatized by what he has just seen, the boy runs back to the shelter. The scene is composed using a combination of medium and long shots. The use of medium-range shots mostly introduces the boy looking for the grains, while the long shots establish the spatial structure which is conveyed through the use of the open space-time strategy.

The scene brings to view the setting, a green paddy field amidst the vast green landscape. The brightness of the sun indicates that it is a clear day; the miseen-scène, to some degree, does exhibit one of Naficy's open space-time features which is the sense of boundlessness. In this scene, the notion of boundlessness is established through the rendering of the vast green landscape conveyed through 
the use of mobile long shots. However, the mise-en-scène does not reveal any indication of the sense of timelessness, an essential temporal aspect of the open space-time formation.

\section{THE SIGNIFICANCE OF SPACES AND PLACES}

In Viduthalai Moochu, the cinematic space-time features play a vital role in presenting the significance of the homeland in the point of view of the displaced and the deterritorialized Eelam-Tamil internal exilic community. In this film, the concept of homeland is an aspect that plays a significant role in expressing the accent of displacement and deterritorialization. The scene is indeed consistent with the markings of the open space-time formation and begins with the sweeping view of the internal exilic enclosure. In this scene, the characteristics of the openness are established through the use of combined extreme long, long, and medium shots that brings to the screen the view the of landscapes at the internal exilic enclosure. The paddy field, in this scene, appears barren and empty, the barren view of the paddy field makes the setting appear somewhat lifeless. Despite the fact that there is green vegetation, mostly thickets and trees, the sight of the empty paddy field overpowers the mise-en-scène. The strategy employed in this scene certainly amplifies the sense of desolation without any indication of lushness.

Looking at the strategy, in terms of timelessness, the boy's unexpected encounter with the dead bodies unequivocally defeats the idea of timelessness. Instead, the view of the dead bodies creates the sense of thanatophobia, the fear of death. Although the strategy strongly indicates the sense of openness, the boy's expressions at the time of the startling encounter distort the configuration of the open spacetime form. The boy's traumatic experience is conveyed through the combination of medium and close-up shots, both static and mobile framing modes; the shots bring the boy's devastating experience through his facial expressions and bodily reactions which are shown on the screen. The sight of the shallow grave drives the boy to a state of shock, panic, and fear. The boy runs for his life. In most "narratives of panic and pursuit," scenes such as these are considered as the common manifestations of the closed form (Naficy 5). The boy's traumatic experience reflects the archetypal symptoms of the closed space-time form. However, the strategy that has been used to construct the space and the place in this scene symptomatically denotes to the distortion of the open space-time formation and disrupts the mise-en-scène that has been specifically constructed to establish the open space-time formation. In fact, conflicting space-time formations should not be seen as distortions or disruptions but as unique configurations that may well compose a dynamic mise-en-scène that can handle both heavy narrative burdens and demonstrations of the accent 
efficiently. Therefore, the distorted or disrupted form of space-time formations could potentially emerge as ideal spatial and temporal configurations that are apt in revealing the distinction between the homeland and the internal exilic enclosure.

Through this scene, the makers of Viduthalai Moochu have indeed efficiently employed the open space-time formation which is also heavily influenced by the closed space-time formations to convey the notion that the internal exilic enclosure is a space and a place that does not convey the sense of contentment, affluence and above all the sense of emancipation. The strategy effectively portrays the internal exilic enclosure as a restricted and a controlled space and place where the EelamTamils are destined to live in fear and trauma. The conjoined configuration of the open and the closed space-time formations has indeed presented a realistic representation of the internal exilic enclosure which appears realistic on the screen.

\section{THE EXPRESSION OF DISPLACEMENT AND DETERRITORIALISATION}

Among the three space-time formations delineated in Naficy's spatial representation modality, in terms of spatial and temporal representation, the open space-time formation best characterizes the imagined and the desired homeland(s). In Viduthalai Moochu, the open space-time feature is employed as a strategy that renders the environs of the internal exilic enclosure. The distortion of the open space-time formation which is quite apparent in this scene proves to be an effective strategy that renders the internal exilic enclosure as an undesired space and place of habitation. In the scene, although the mise-en-scène indicates that the setting of the internal exilic enclosure is rendered through the configuration of the open spacetime formations, the sense of openness appears distorted and flawed as a result of the overpowering influence of the closed space-time formation. Given this, Naficy argues that all the three spaces tend to "reinforce, coexist with, or contradict one another" (153). In the film, the distorted form of the open space-time strategy best demonstrates the accent of displacement and deterritorialization of the internally displaced Eelam-Tamils in the internal exilic enclosure. In her observations of external exilic films and filmmakers, Suner affirms that even prominent exilic filmmakers like Ghobadi, Wong, and Ceylan have also exploited the irregular or abnormal articulation of space-time configurations that at times contradict with one with another. Therefore, distorted or flawed space-time features can be used as effective strategies that best illustrate the experiences of internal exile. For instance, the scene at the paddy field where graves of dead Eelam-Tamils were found is a visible indication that the sense of home does not exist in this space and place. According to Halleh Ghorashi, within the exilic discourse, home is a space and a place where exiles do not live (133). The film effectively renders this notion through 
the distorted configuration of the open space-time strategy which effectively brings across the idea that for the Eelam-Tamils there is no sense of home in the internal exilic enclosure.

From this scene, it is quite evident that the makers of Viduthalai Moochu have indeed exploited the configuration of the open space-time formation to compose a mise-en-scène that renders every single detail of the environs and the conditions in the internal exilic environment. The makers of the film could have employed this strategy to highlight the ambiguity of whether the Eelam-Tamils have occupied the space and the place or have become occupied by it. The employment of conflicting space-time formations offers better perspectives in understanding the film's narrative, purpose and historical precedence, and the predicament of the EelamTamils at the internal exilic enclosure. The technique employed by the filmmakers is to present a relatively symbiotic connection between the open and the closed space-time formations; such strategies are common in the accented filmmaking style.

The other manifestations of the open space-time formations in the film also seem to reflect the same pattern of unusual spatial and temporal configurations where the open space-time formations appear weak and suppressed. It is evident that the open space-time formation does dominate any scenes in the film. Therefore, in Viduthalai Moochu, the open space-time formation is a spatial and temporal configuration that only coexists with the closed space-time formations. The reason for this could owe to the fact that the film is purely a narrative of internal exile which is produced by the displaced and the deterritorialized filmmakers who still live in the internal exilic enclosure. As an effort to highlight the troubling effects of displacement and deterritorialization, the film least exemplifies the sense of liberation and openness. Interestingly, unlike the open space-time formations, the closed space-time formations in the film are manifestly dynamic and forceful.

\section{THE CLOSED SPACE-TIME FORMATION IN THE TORTURE CHAMBER SCENE}

As dominant spatial configurations in the film, the closed space-time formations are used continuously throughout the film to highlight the conditions and the sufferings of the Eelam-Tamil characters. One such scene renders the interior view of a military torture chamber where few Eelam-Tamils are shown being forcefully detained at the torture chamber. From this scene, we can see that the torture chamber is not only a place of torture, it is also a place of inquisition which is specially constructed to muffle the screams that come from the tortured detainees. The interior structure of the torture chamber is also used as a space 
that implies regimental supremacy of the military over the internally exiled EelamTamil people. In this scene, the portrayal of the torture chamber represents the absolute embodiment of the closed space-time formation. The visuals of the torture chamber's interior space demonstrate the employment of the preferred camerawork of the closed space-time formation: medium close-ups and close-up shots. The torture chamber is mostly rendered through the use of medium closeups and close-up shots which effectively highlights the interior space of the torture chamber.

The mise-en-scène reveals a night scene, shot in a darkly lit cell using the low-key chiaroscuro lighting scheme. The technique creates the effects of uneven lighting which make some parts of the cell appear dark, while the other parts of the chamber are presented through the reflections of the low-key lighting scheme. The same technique has also been used to show the descending effects of light on a particular direction, especially to reveal or to emphasize the expressions and the sufferings of the detainees while being tortured by the military men. Limited dialogues and lack of explanations contribute much to the subjectivity of the narrative. The pervasive "subjectiveness" that haunts the film makes the scene that renders the interior view of the torture chamber appear inherently expressionistic. The employment of the expressionistic style which is a cinematic strategy is a clear indication that the filmmakers have resorted to the use of subjectivity. In this scene, subjectivity together with the characteristics of the closed space-time formation is employed as the cinematic means to radically reinforce the scene to create convincing emotional effects that could potentially evoke specific moods, meanings, and sensations that are required in the process of scene compositions. The use of expressionistic approach in this scene could also be seen as the cinematic effort to channel the filmmakers' real-life experiences into the narrative form. It is quite apparent that the makers of this film have established the fact that there could be no room for conversations in a torture cell, except for one or two lines of verbal threats by an oppressor; the scene does not engage in any form of speech. Moreover, the scene does not provide any form of information, reason, or explanation of what is transpiring in the torture chamber.

\section{THE SIGNIFICANCE OF SPACES AND PLACES}

The internal exilic experience is indeed an intense, devastating experience of social fracture, not that the other experiences, diasporic, external exilic and post-colonial ethnicity, are far less intense. The film's depiction of the Eelam-Tami internal exilic experience effectively conveys the idea that the destiny of Eelam-Tamil internal

exiles is entirely at the mercy of the ruling regime which is, in the film, represented

Kritika Kultura 33/34 (2019/2020): 494-502

(C) Ateneo de Manila University

<http://journals.ateneo.edu/ojs/kk/> 
by the military. Purposively, the film, Viduthalai Moochu articulates the devastation of the Eelam-Tamil internal exilic experience through the spatial and temporal representations of the internal exilic enclosure. One such manifestation that genuinely mirrors the internal exilic enclosure is none other than the torture chamber. The scene reveals the exterior as well as the interior space of the torture chamber. In the interior space, the Eelam-Tamil detainees are subjected to all sorts of physical and psychological torments. For instance, in one of the frames in the scene, a superior military officer is shown daunting a female detainee, a young Eelam-Tamil girl. The officer tells the girl that he desires her, and she has no other options but to give in to his demands; he even warns that she will eventually have to give in. In terms of spatial construction, the interior space of the torture chamber which is fundamentally composed in accordance with the closed space-time strategy establishes the torture chamber as a space and a place of indefiniteness where the Eelam-Tamils are destined to lose all the trappings of identity and belonging. The scene establishes the notion that the torture chamber is a space and a place where the Eelam-Tamils were subjected to extreme psychological and physical torments. The portrayals of the ongoing torment of the Eelam-Tamil in the interior space of the torture chamber suggest that the spatial and temporal configuration of the closed-space-time formation is also hinged on the notion of suffering and possible death. In terms of the accent, the structural and the environmental aspects of the torture chamber is exceptionally faithful to the characteristics of the closed spacetime formation as for how it has been delineated in the theorization of An Accented Cinema. In the scene, the spatial aspects of the closed space-time formation which is manifestly revealed through the scene's mise-en-scene which consists of interior locations and closed settings, such as, "prisons and tight living quarters, a dark lighting scheme that creates a mood of constriction and claustrophobia, and characters who are restricted in their movements and perspective by spatial, bodily, or other barriers" (Naficy 153).

The shots and framing that has been used in the portrayal of the interior space of the torture chamber are made of "tight shot composition, static framing, and barriers within the mise-en-scene, and in the shots, foreground suggests closedness" (Naficy 153). In the scene, the torture chamber, which is an actual embodiment of the Eelam-Tamil experience in the internal exilic enclosure is also depicted as a space and a place of forced habitation. Apart from that, the torture chamber is also rendered as a space and a place where the Eelam-Tamils are subjugated through torment and torture. 


\section{THE EXPRESSION OF DISPLACEMENT AND DETERRITORIALISATION}

The film establishes the fact that in the internal exilic dwelling or experience, the feeling of being a part of the homeland is not there. In the film, the torture chamber is rendered not only as a structure that deconstructs both the notion of home and homeland but also as a structure that establishes the internal exilic enclosure as a mere space and place of habitation where the internal exiles are forced to dwell in subjugation and fear. As one of the prevailing representations of the internal exilic enclosure, the torture chamber is a structure that demonstrates all the indications of the displacement and the deterritorialization of the Eelam-Tamil internal exiles. The film employs the use of the closed space-time formation as a primary strategy that characterizes the torture chamber both externally and internally. The external and the internal spatial characteristics of the torture chamber are expressed through the notion of constriction, confinement, imprisonment, limitation, oppression, subjugation, isolation, trauma, and claustrophobia which are visually conveyed through the forced imprisonment of the Eelam-Tamils.

The scene which depicts the environment of the torture chamber effectively brings across the sense of panic, fear, and trauma. The incarceration of the EelamTamils in the hands of the military which is revealed through the framing style, lighting scheme, and shots evidently exhibit the full use of the closed space-time formation. In this sense, as a space and a place of forced habitation, the torture chamber accentuates the position of the detainees as the displaced and the deterritorialized. The spatial and temporal characteristics of the torture chamber also establish the notion of isolation. The scene brings the view of the inhabitants who are detained; the sight of the confined detainees placed in isolated cells naturally evokes the ambience of imprisonment, oppression, and alienation. The mise-en-scène establishes this through the renderings of the torture chamber's interior space in terms of its structure, and spatial and environmental aspects.

The use of the closed space-time strategy in this scene aesthetically portrays the torture chamber as a space and a place that connotes the displacement and deterritorialization of the Eelam-Tamil experience in internal exile. The torture chamber is also rendered as a space and a place that affirms the intention of the military regime which is to confine, constrict, and incarcerate the Eelam-Tamils.

\section{THE THIRD SPACE-TIME FORMATION FEATURE IN THE STREET SCENE}

The conflation of space-time formations is not an unusual practice in the accented

cinema. However, there are vast differences between the regular conflating 
space-time formations and the conflation of space-time formations that form the third space-time formation. Unlike the regular conflating space-time formations which are usually meaning-motivated, the conflation of space-time formations which forms the third space-time formation is hinged on the idea of transition and liminality. In the film, the street scene best exhibits the characteristics of the third space-time formation. The scene renders the view of a quotidian space and place in the internal exilic enclosure, a street which is entirely occupied by the military. Each frame in the scene is dominated by the presence of soldiers and military vehicles. Although there are many such scenes in the film, however, this scene fully exhibits the spatial and temporal characteristics of the third space-time formation. The external view of the street is indeed in line with the spatial aspects

of the open space-time formation such as open framings, settings, and lighting scheme. At the same time, the overpowering presence of the military occupying the street demonstrates the characteristics that are typically associated with the closed space-time formation such as closed settings where the characters are restricted in their movements and perspective by spatial, bodily, or other barriers. In this scene, the overpowering presence of the military represents such barriers.

\section{THE SIGNIFICANCE OF SPACES AND PLACES}

The street scene is certainly a paragon of the third space-time formation in the film. In this film, the street is one of the central representations which is used in the film to insinuate the notion that the internal exilic enclosure is a forced, restricted, and a traumatic space and place of habitation for the Eelam-Tamils. Aesthetically, the view of the street is conveyed through the configuration of open space-time formation. The mise-en-scène exhibits much of the open space-time spatial characteristics, such as, framings, shots, and lighting scheme and does not show any signs or indications of the open space-time's temporal and psychological characteristics, which provide the sense of timelessness and boundlessness. However, the presence of the prowling military vehicle demonstrates the temporal and psychological characteristics of the closed space-time formation. The conflation of the spatial characteristics of the open space-time and the temporal and psychological characteristics of the closed space-time renders the street as a restricted and a prohibited space and place. The scene shows that except for the military vehicle, there are no other vehicles or people occupying the street. Metaphorically speaking, the street appears like a skeleton, stripped of its flesh, bare and with an uncanny calmness. Just like the paddy field and grave scene, the mise-en-scène also establishes the sense of desolation with no indication of lushness. 
In terms of timelessness, the sight of the military vehicle traversing the street obliterates the idea of timelessness and evokes the sense of fear and phobias, the typical signs of the closed space-time formation. The notion of fear and phobia is further demonstrated through the rendering of the military jeep which is equipped with a machine gun; the presence of the military jeep distorts and overpowers the spatial influence of the open space-time formation. The sight of the traversing jeep which is also consistent with what Naficy identifies as the narratives of panic and pursuit is conveyed through the employment of the closed space-time formation. The mise-en-scène of the patrolling army jeep is cinematically constructed through the combination of medium and close-up shots through a sequence of static and mobile framing while maintaining the preferred lighting scheme of the open spacetime strategy which is the use of bright natural sunlight. The strategies used to present the view of the street and the presence of the military jeep affirms that the scene has indeed been composed using the third space-time formation which is characterised by the influence of the open and closed space-time formations.

Through this scene, the producers of Viduthalai Moochu have efficiently employed the third space-time formation as an accented cinematic feature to highlight the street as a liminal and a transitional space and place that does not express the sense of contentment, affluence and above all the sense of emancipation. The strategy successfully portrays the street as a restricted and a controlled zone where the internally exiled Eelam-Tamils are destined to live in subjugation and fear. The conjoined configuration of the open and the closed space-time characteristics of the third space-time formation has indeed presented a realistic representation of the internal exilic enclosure through the rendering of the street as a quotidian space and place. The employment of third space-time feature as a strategy to render the significance of the street in the internal exilic enclosure not only expresses the ongoing trauma and the dilemma of the Eelam-Tamil experience, the street scene also reflects the filmmakers' preoccupation with the estranged environment of the internal exilic enclosure. In the scene, the rendering of the street through the configuration of the third space-time formation has conveyed the notion that the internal exilic enclosure is a space and a place of forced habitation. Through this scene, the filmmakers have employed the configuration of space and place to establish the sense of dépaysement and alienation of the Eelam-Tamil experience in the spaces and places they have been forced to inhabit. In the internal exilic enclosure, the Eelam-Tamil internal exiles are constantly monitored, and their movements restricted. 


\section{THE EXPRESSION OF DISPLACEMENT AND DETERRITORIALISATION}

In the internal exilic enclosure, the living conditions of the internally exiled EelamTamils resemble the treatment of animals in zoos and animal enclosures and limited movement in confinement. This notion is demonstrated in this scene through the spatial and temporal configuration of the third space-time formation. In this scene, the street, a quotidian space and place of the internal exilic enclosure underlines the displacement and the deterritorialization of the Eelam-Tamil experience in internal exile. The rendering of a barren street and the uncanny presence of the military vehicle which is shown invading and occupying the space and place spells this out clearly. The presence of the military vehicle forms the central trauma of the scene and establishes the prefiguring of adversities, danger, anxiety, and fear that await those who occupy the street.

The scene highlights the predicament of the Eelam-Tamils who have been forced into internal exile. The confinement of the Eelam-Tamils symbolically expresses the dilemma of being denied fundamental freedom. The scene shows that there is a prohibition to occupy quotidian spaces and places such as the street. The displacement and the deterritorialization of the Eelam-Tamil internal exiles are revealed through the psychological and emotional constraints of those who wish to occupy the street and the ominous presence of the military that would prevent them. Fundamentally, the third space-time formation is an accented feature that can be best described by its spatial and temporal characteristic, such as, liminality, impermanence, and danger. The cinematic connotations of the accent that can be drawn from this scene illustrate the ongoing terror, fear, and trauma and the prohibitions of various types through the rendering of the all-prevailing presence of the military vehicle occupying a public quotidian space and place. The presence of the military vehicle which is strongly characterized by the influence of the close space-time configuration efficiently conveys the notion of imposed restrictions and deprivations of the Eelam-Tamil experience in the internal exilic enclosure.

\section{CONCLUSION}

The paper shows that film Viduthalai Moochu is indeed an internal exilic accented film that reveals the Eelam-Tamil filmmakers' preoccupation with the exilic enclosure, especially through the use of the spatial representation modality that entails the open, closed, and third space-time formations. Since the film is entirely made in the exilic enclosure, the spatial representation modality appears to be the dominant cinematic feature that expresses an "intentional" style of filmmaking

which is mainly driven by the accent. All the three space-time formations also 
draw attention to how the filmmakers perceive the landscapes and the surrounding environment as cinematic spaces that express the displacement and the deterritorialization of the Eelam-Tamil people. Therefore, the paper shows that the formulation of the filmmakers' preoccupation with the space and the place which is expressed through the open, closed, and third space-time formations proves to be an effective analytical means of deciphering the portrayals of spaces and places rendered in the film, especially in an internal exilic film, such as Viduthalai Moochu. The paper also shows that regardless of their disposition, accented filmmakers from different parts of the world are increasingly focusing on subjects that concern the interstices of cultures and social realism. The accented style is an emerging form of filmmaking which indeed has the potentials to cinematically illustrate the aspects that signify the fractures of the social fabric. The accented cinema's fascination with the representations of spaces and places suggests that this new genre will be continuously explored across many disciplines. 


\section{Works Cited}

Bakhtin, M.M., M. Holquist, and C. Emerson. The Dialogic Imagination: Four Essays. U of Texas P, 2010.

Brown, Cynthia G. Playing the "Communal Card": Communal Violence and Human Rights, edited by Cynthia G Brown and Farhad Karim, Human Rights Watch, 1995.

Bartholomeusz, Tessa J., and Chandra Richard De Silva. Buddhist Fundamentalism and Minority Identities in Sri Lanka. State U of New York P, 1998.

Boyle, F. The Tamil Genocide by Sri Lanka: The Global Failure to Protect Tamil Rights under International Law. Clarity Press, 2013.

Colletta, Nat J., Teck Ghee Lim, Anita Kelles-Viitanen. Social Cohesion and Conflict Prevention in Asia: Managing Diversity through Development. World Bank, 2001.

Derges, J. Ritual and Recovery in Post-Conflict Sri Lanka. Taylor and Francis, 2013.

Distant. Dir. Nuri Bilge Ceylan. Perf. Muzaffer Özdemir, Emin Toprak, Zuhal Gencer, Mongrel Media, 2002.

Ezra, E., and T. Rowden. Transnational Cinema: The Film Reader. Routledge, 2006.

Fernando, Sriyantha, Jayatilleke S. Bandara, Susantha Liyanaarachch, Ruwan Jayathilaka, and Christine Smith. "Political Violence and Volatility in International Tourist Arrivals: The Case of Sri Lanka." Tourism Analysis, vol. 18, no. 5, 2013, pp. 575-86.

Fowler, Catherine, and Gillian Helfield. Representing the Rural: Space, Place, and Identity in Films about the Land. Wayne State UP, 2006.

Ghorashi, H. Ways to Survive, Battles to Win: Iranian Women Exiles in the Netherlands and United States. Nova Science Publishers, 2003.

Gow, C. From Iran to Hollywood and Some Places In-between: Reframing PostRevolutionary Iranian Cinema. I. B. Tauris, 2011.

Hanson, Lance. "Edgelands Aesthetics: Exploring the Liminal in Andrea Arnold's Fish Tank (2009)." Writing Visual Culture: Between Texts and Cities, vol. 6, 2015, p. 65.

Herrera, A.O.R. Cuba: Idea of a Nation Displaced. State U of New York P, 2008.

Houen, A. States of War since 9/11: Terrorism, Sovereignty and the War on Terror. Taylor and Francis, 2014.

Hyndman, Jennifer. "Aid, Conflict and Migration: The Canada-Sri Lanka Connection." The Canadian Geographer/Le Géographe Canadien, vol. 47, no. 3, 2003, pp. 251-268.

Kalmanowitz, D., and B. Lloyd. Art Therapy and Political Violence: With Art, without Illusion. Routledge, 2005.

Koneswaran, Gowri. "(Q and A) with Tamil Poet R. Cheran on Poetry in the Face of Oppression." The Alignist LLC, 2015. http://www.thealignist.com/ article /2015/12/21/r-cheran. Accessed 12 Apr. 2018.

Naficy, H. An Accented Cinema: Exilic and Diasporic Filmmaking. Princeton UP, 2001.

No One Knows about Persian Cats. Dir. Bahman Ghobadi. Perf. Negar Shaghaghi, Ashkan Koshanejad, Hamed Behdad, 2009.

Prince, G. A Dictionary of Narratology. U of Nebraska P, 2003. 
Roy, K., and S. Gates. Unconventional Warfare in South Asia, 1947 to the Present. Taylor and Francis, 2017.

Samaranāyaka, G. Political Violence in Sri Lanka, 1971-1987. Gyan Publishing House, 2008.

Sefton-Green, J., and J. Rowsell. Learning and Literacy over Time: Longitudinal Perspectives. Taylor and Francis, 2014.

Suner, Asuman. “Outside In: 'Accented Cinema' at Large." Inter-Asia Cultural Studies, vol. 7, no. 3, 2006, pp. 363-382, doi:10.1080/14649370600849223.

Viduthalai Moochu. Dir. K. Ramaesh and S. Vinothan. Perf. Thava, Ramesh, Neethan, Kani, Ushanthan, Tamil Media House, 2002.

Weerawansa, Dinesh. "The Latest 'Horror Drama." Archive Today, 30 Dec. 2010, http:// archive.is/G9Dr. Accessed 4 May 2017. 